\title{
Steam drying compared to drum drying markedly increases early phase rumen fermentability of sugar beet pulp*
}

\author{
Verdampfungstrocknung im Vergleich zur Trommeltrocknung erhöht deutlich \\ die frühe Fermentation von Zuckerrübenschnitzeln im Pansen
}

Freshly pressed and dried sugar beet pulp was sampled from 2 different factories located within a distance of $30 \mathrm{~km}$ and on 4 different dates. One factory was equipped with a steam dryer and the other with a drum dryer. A recognized in vitro technique was used to establish, how the drying process affected rumen fermentability of the pulp, since fibrous feeds (such as sugar beet pulp) rely on microbial fermentation in the rumen to be digestible to the cow. Steam dried pulp had a remarkable $>60 \%$ higher fermentability compared to drum dried pulp during the first 12(-15) hours of fermentation, but there were no differences in fermentation pattern after 24 hours of fermentation. The increased early fermentability must markedly increase the nutritional value for high-yielding dairy cows, which at feed intakes of $25 \mathrm{~kg}$ dry matter or more, have retention times in the rumen for water soluble compounds (such as pectin) and small particles as low as 6.7-13.3 hours. Future feeding trials are needed to establish exactly how much the feeding value is increased in steam dried sugar beet pulp.

Key words: in vitro gas production, digestibility, fiber degradability, feed value, dairy cattle

\section{Introduction}

The demand for pollution free and energy saving drying technology has been the incentive for the development of a new concept for drying of beet pulp in a fluid bed under steam pressure as an alternative to the traditional drying in indirect fired rotation drums [1]. The first-generation steam dryer was developed in Denmark between 1981 and 1990. Since 1998, high-yielding steam dryers have been marketed and continuously refined by Enerdry A/S (Virum, Denmark). The concept underlying the pressurized steam dryer (Fig. 1) is that the drying takes place in super-heated water steam under pressure in a closed vessel. The moist material (pressed beet pulp) is brought into the pressure vessel with a rotary valve. Inside the vessel the beet pulp is dried by super-heated steam in a fluid bed divided into several chambers. The super-heated steam is circulated inside the vessel and is reheated by a heat exchanger. The steam which is generated (water originated from the pulp)
Frisch gepresste und getrocknete Schnitzel wurden an vier verschiedenen Terminen aus zwei $30 \mathrm{~km}$ voneinander entfernten Fabriken entnommen. Die eine Fabrik ist mit einem Verdampfungstrockner und die andere mit einem Trommeltrockner ausgerüstet. Eine anerkannte In-vitro-Technik wurde genutzt, um festzustellen, wie der Trocknungsprozess die Fermentierbarkeit der Schnitzel im Pansen beeinflusst, da faseriges Futter (wie z.B. Zuckerrübenschnitzel) auf die mikrobielle Fermentation im Pansen angewiesen ist, um für die Kuh verdaubar zu sein. Verdampfungsgetrocknete Schnitzel waren merklich besser fermentierbar (>60\%) im Vergleich zu trommelgetrockneten Schnitzeln während der ersten 12 (-15) h der Fermentation, aber es gab keine Unterschiede nach 24 h. Die erhöhte frühe Fermentierbarkeit müsste den Nährwert für Hochleistungs-Milchkühe deutlich erhöhen, die bei Futteraufnahme von $25 \mathrm{~kg}$ Trockenmasse - oder mehr - Retentionszeiten von 6,7-13,3 h im Pansen für wasserlösliche Verbindungen (wie Pektin) und kleine Teilchen aufweisen. Künftige Fütterungsversuche sind erforderlich, um genau festzustellen, wie sehr der Futterwert verdampfungsgetrockneter Zuckerrübenschnitzel erhöht wird.

Schlagwörter: in vitro-Gasproduktion, Verdaulichkeit, Faserabbaubarkeit, Futtermittelwert, Milchvieh

is extracted from the vessel at about 3.7 bar (abs). This steam is used in the first effect evaporator in the sugar factory. So, in other words, the steam dryer "borrows" the energy from the supply steam and supplies it back with 3.7 bar (abs), in contrast to a drum dryer which loses all the energy in the stacks. Therefore, steam drying reduces the large energy consumption usually required for drum drying by almost $100 \%$. The reduction is equivalent to $125 \mathrm{t}$ of coal per campaign-day at a 10,000 t/d beet sugar factory, amounting to a reduction in $\mathrm{CO}_{2}$ emission of appr. $358 \mathrm{t}$ per campaign-day. Furthermore, the steam dryer completely eliminates the air pollution (volatile organic compound [VOC] and dust emission) compared to the classic drum dryers.

Today, appr. 25 steam dryers exist around the world, producing appr. $1 \mathrm{mn} \mathrm{t}$ of dried beet pulp per year. Steam drying

\footnotetext{
* Paper presented at the ESST Conference 2017 in Dresden, Germany, May 21-24.
} 


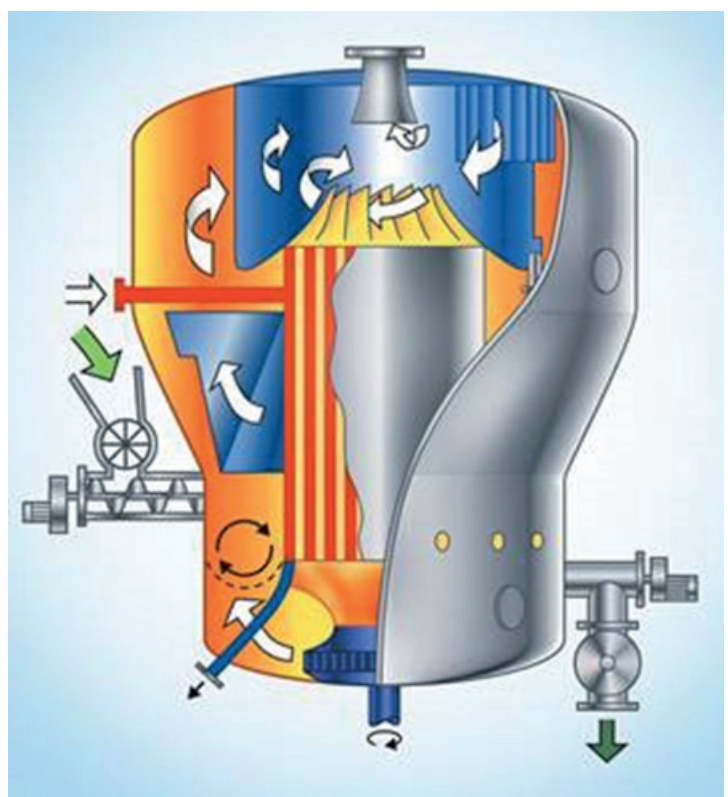

Fig. 1: Schematic presentation of steam dryer

Green arrows symbolize how pressed pulp enters and exits the steam dryer, through the rotary valves. When the pulp is inside the steam dryer, it is kept suspended in a fluidbed by steam, symbolized by the white arrows. The main fan at the bottom blow the heated steam up through perforated plates whereon the pulp is kept swirling. The circulating steam is dedusted in the top in a cyclone, before either entering the centered heat exchanger or exiting the steam dryer in the top.

plants are appr. 50\% costlier to establish than a drum drier, and they have therefore mainly been installed due to the large savings on consumption of energy, which is obviously also associated with substantial reductions of emissions to the atmosphere.

The dried beet pulp is predominantly marketed as a valuable feed for dairy cows, rich in soluble and easily fermentable dietary fibers. No mammals synthesize enzymes capable of degrading dietary fibers, and the ability to digest dietary fibers can entirely be ascribed to microbial fermentation in the gut. In dairy cows (and other ruminant animals), the fermentability of dietary fibers in the rumen is the main factor determining overall digestibility and hence energetic value of these dietary fibers. Fermentability of dietary fibers in the rumen is also a key determinant for the supply of energy to sustain microbial protein synthesis in the rumen, which in turn is important for the supply of essential amino acids for milk protein synthesis in the cow. It can be observed that beet pulp dried by steam drying typically has a lighter color and less extensive dark colorations of the edges of the pulp flakes compared to pulp dried in a drum dryer (Fig. 2), which presumably is due to more extensive burning in the presence of oxygen in drum dryers. It is unknown whether the differences caused by drying techniques have implications for rumen fermentability and therefore the energetic value and protein value of dried beet pulp products for dairy cows. This is an important issue to consider, along with the energy consumption and total yield of dry matter produced by the two drying methods, when new drying plants are being planned.

The objective of the present study was to assess how steam versus drum drying affects rumen fermentation of beet pulp in the forestomachs of cattle. To address this objective, we assessed rumen degradability of paired samples of freshly pressed and dried beet pulp from two neighboring sugar factories, one equipped with a drum dryer and the other with a steam dryer. Degradation profiles during fermentation were determined using the in vitro vented gas production (IVGP) technique, which has been used for ruminant feed degradation evaluation since the late 1970's [2]. It is considered a useful methodology to simulate rumen degradation of feed stuffs as discussed by Hannah et al. [3], since the volume of gas produced during fermentation of a feed with a rumen buffered inoculum reflects the degradation of organic matter by rumen microbes during fermentation. Thus, information about both the kinetics of rumen degradation (fermentation) through time as well as the maximal potential degradability of a feed in the rumen can be obtained using the IVGP technique.

\section{$2 \quad$ Materials and methods \\ 2.1 Sugar beet pulp samples and processing}

Paired representative samples of freshly pressed sugar beet pulp and dried pulp were collected on four different dates (26 October, 08 November, 07 December and 30 December 2016) from two different sugar factories located in the same region approximately $30 \mathrm{~km}$ apart. One factory was equipped with a coal fired drum drier and the other with a steam dryer (EnerDry size J, Enerdry A/S, Virum, Denmark). Samples of the pressed or dried pulp was immediately transferred to a container, which was sealed and stored frozen at $-20{ }^{\circ} \mathrm{C}$ pending further analyses.

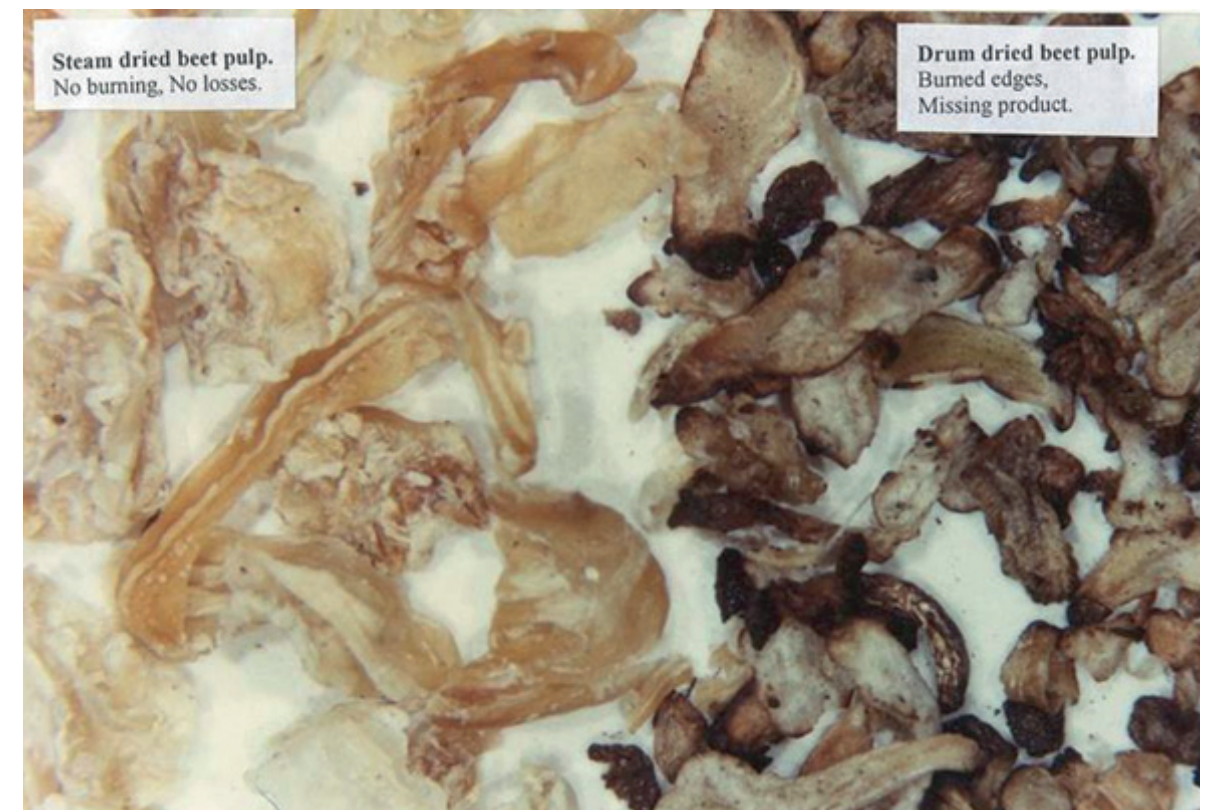

Fig. 2: Appearance of beet pulp dried in a steam dryer (left) and drum dryer (right). Note the lighter color of the steam dried pulp and the burned edges of the drum dried. 
Dry matter (DM) and ash content in the collected freshly pressed and dried pulp samples from the two factories were determined by drying to constant mass at 102 and $500{ }^{\circ} \mathrm{C}$, respectively.

For in vitro gas production trials (see section 2.2), samples of freshly pressed and dried beet pulp were freeze dried for 4-7 d until a constant mass was achieved and then ground through a $1 \mathrm{~mm}$ sieve. DM content in the freeze dried samples was determined by further drying at $102^{\circ} \mathrm{C}$ for $24 \mathrm{~h}$.

\subsection{In vitro vented gas production (IVGP) trials}

Two different IVGP trials were conducted according to the design depicted in Figure 3. For each trial, rumen fluid was collected freshly and mixed from 2 different rumen cannulated non-pregnant and non-lactating Jersey cows. The cows were fed at maintenance level with hay and housed at the experimental station "Rørrendegård", University of Copenhagen, Denmark. All procedures involving the experimental cows were approved by the National Committee on Animal Experimentation, Denmark.

In each of the two identically designed IVGP trials, $500 \pm 30 \mathrm{mg}$ of each ground sample was weighed into $100 \mathrm{~mL}$ Duran ${ }^{\circledR}$ bottles (total volume of $132 \pm 1 \mathrm{~mL}$ when completely filled with fluid). Three replicates were made for each sample. The samples were tested without identification of the processes the samples had undergone, but the pairs of original and processed samples were identified by a code. The factory and process information was provided after the experiment was concluded.

The inoculum consisted of a mixture of a buffer solution and rumen fluid. The buffer solution was prepared as described by Menke and Steingass [4] and was kept at $39^{\circ} \mathrm{C}$ and flushed continuously with $\mathrm{CO}_{2}$ for 2 to $3 \mathrm{~h}$ before addition of the rumen fluid. A reduction agent (containing sodium hydroxide and sodium sulfide) was freshly prepared and added to the buf- fer, in order to ascertain anaerobic condition, shortly before rumen fluid addition.

The rumen fluid, including particulate matter, was collected from the cows before morning feeding and transferred to preheated thermo bottles. Upon arrival (appr. 30 min later) at the laboratory, the rumen fluid was filtered through two layers of cheesecloth to eliminate large feed particles and the $\mathrm{pH}$ value of the filtered rumen liquor was measured. The buffer was mixed with rumen liquor in a 2:1 ratio, and the initial $\mathrm{pH}$ value of the buffered rumen inoculum was between 6.8-6.9. $90 \mathrm{~mL}$ of this inoculum was added to each Duran ${ }^{\circledR}$ bottle.

The headspace of each bottle was thereafter flushed with $\mathrm{CO}_{2}$, and closed with a module head fitted with an automatic wireless IVGP module (Ankom Technology, Macedon, NY, USA) with pressure sensors (pressure range: from -69 to $+3447 \mathrm{kPa}$; resolution: $0.27 \mathrm{kPa}$; accuracy: $\pm 0.1 \%$ of measured value). Each module sends measurements via a receiving base station to an attached computer. The gas was automatically released (250 ms vent opening), when the pressure inside the bottles reached $3.447 \mathrm{kPa}$ above the ambient pressure. The absolute pressure in the bottles was recorded every $10 \mathrm{~min}$ and accumulated pressure of released gas was calculated. The incubation was conducted at $39^{\circ} \mathrm{C}$ for $48 \mathrm{~h}$ in a thermoshakerincubator. After $48 \mathrm{~h}$ of incubation, the fermentation was concluded by transferring the bottles into an ice bath to stop microbial activity.

After termination of the incubation, undegraded sample DM remaining in the fluid was collected by filtering contents of the Duran ${ }^{\circledR}$ bottles through a $25 \mu \mathrm{m}$ pore size F57 (Ankom Technologies) filter bag, and the total amount of DM that had been degraded was then calculated. Two bottles containing inoculum, but with no sample (blanks) were included to establish baseline fermentation gas production derived from the inoculum itself over the incubation period and to be able to correct for retention of microbial dry matter in filter bags, which was derived from the buffered rumen fluid itself.

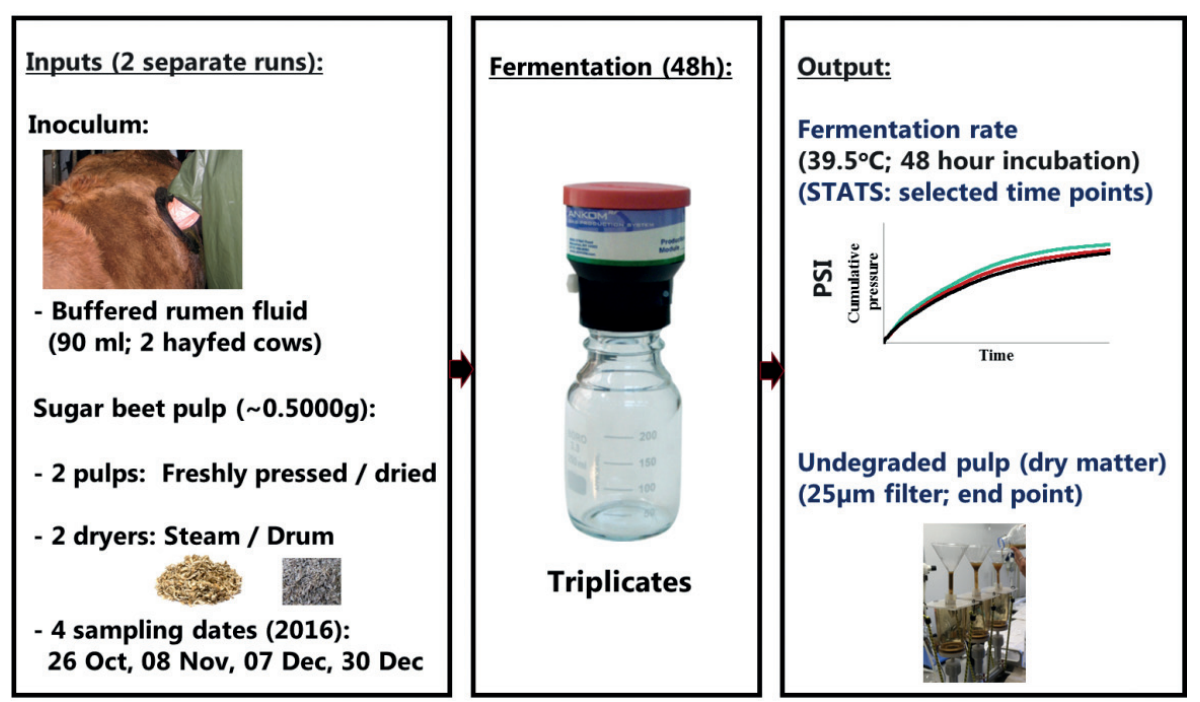

Fig. 3: Experimental design of in vitro vented gas production (IVGP) trials

Paired samples of freshly pressed and dried beet pulp were sampled on 4 different dates from two different factories (one with a steam dryer and one with a drum dryer) and incubated in buffered rumen fluid at $39^{\circ} \mathrm{C}$ for $48 \mathrm{~h}$, and the accumulated pressure of gas produced during the fermentation was continuously recorded. Thereafter, undegraded sample pulp was collected by filtering and the mass determined.

\subsection{Calculations and statistical analyses}

Blank corrected accumulated gas pressure results were converted to $\mathrm{ml}$ gas at standard pressure and temperature (STP: 1 bar and $0{ }^{\circ} \mathrm{C}$ ) by applying the ideal gas law equation and assuming that gasses produced during fermentation (predominantly $\mathrm{CO}_{2}$ and $\mathrm{CH}_{4}$ ) have close to ideal gas properties.

Accumulated gas production at STP after $1,3,6,12,18,24$, and 48 h of incubation was calculated per gram sample DM for each of the 4 different samplings dates. Two-tailed $t$-tests with homoscedastic variance were used to investigate whether the cumulated gas production per $g$ DM at the different time points and total DM degradation (after $48 \mathrm{~h}$ of incubation) were similar for the freshly 
pressed beet pulp samples obtained from the two different factories, and for beet pulp dried in a drum dryer and steam dryer. One tailed $t$-test with homoscedastic variance was used to test for each type of dryer (factory), whether dried beet pulp had positive effect on the fermentation characteristics compared to the pressed (undried) pulp. Significance was declared when $P<0.05$.

\section{Results}

There were no differences between the freshly pressed beet pulp sampled at the two different factories at any of the four sampling dates for any of the determined parameters (content of DM, ash and organic matter as well as accumulated gas production during fermentation and total DM degradability after $48 \mathrm{~h}$ of incubation) (results not shown).

Figure 4 shows that drying of beet pulp in a drum dryer did not alter the pattern of gas production (fermentability) compared to the freshly pressed beet pulp, and total DM degradation after $48 \mathrm{~h}$ of incubation was also identical in the drum dried and freshly pressed pulp feed stock.

However, after drying in a steam dryer, the rate of gas production was increased during the first $12-15 \mathrm{~h}$ of fermentation compared to the freshly pressed feed stock. This was observed in pulp sampled on each of the 4 different sampling dates. After $15 \mathrm{~h}$, this difference between steam dried and freshly pressed pulp gradually disappeared, and after $48 \mathrm{~h}$ of incubation, the total cumulated gas production (Fig. 5) and DM degradability (results not shown) ended at the same level for steam dried and freshly pressed pulp.

Thus, sugar beet pulp dried by steam drying was found to have a markedly faster rate of fermentation (degradability) during the first $12-15 \mathrm{~h}$ of incubation, and $>60 \%$ more gas had been produced after $9 \mathrm{~h}$ incubation in steam dried as compared to drum dried beet pulp (Fig. 6). This difference between steam and drum dried pulp gradually disappeared after more than $15 \mathrm{~h}$ of fermentation, and the total gas production and DM degradability after $48 \mathrm{~h}$ of incubation were identical in steam dried and drum dried pulp.

\section{Discussion}

The results of this experiment clearly demonstrated that the steam drying process altered the pattern of degradation of beet pulp in the rumen compared to the freshly pressed pulp (feed stock) in such a way that microbial fermentation of the pulp was initiated earlier and continued to have a higher fermentability during the first 12(-15) h of incubation (Fig. 5), whereafter the difference disappeared. Hence, the potential DM degradability and total accumulated gas production after $48 \mathrm{~h}$ of fermentation (end-points) were not affected.

The drum drying process did not have a similar impact on early fermentation. If anything, there was in fact a slight tendency for a numerical decrease in early fermentability of the drum dried pulp compared to the freshly pressed feed stock (Fig. 4). Consequently, rumen fermentability of beet pulp dried in a steam dryer was higher than that of drum dried pulp over

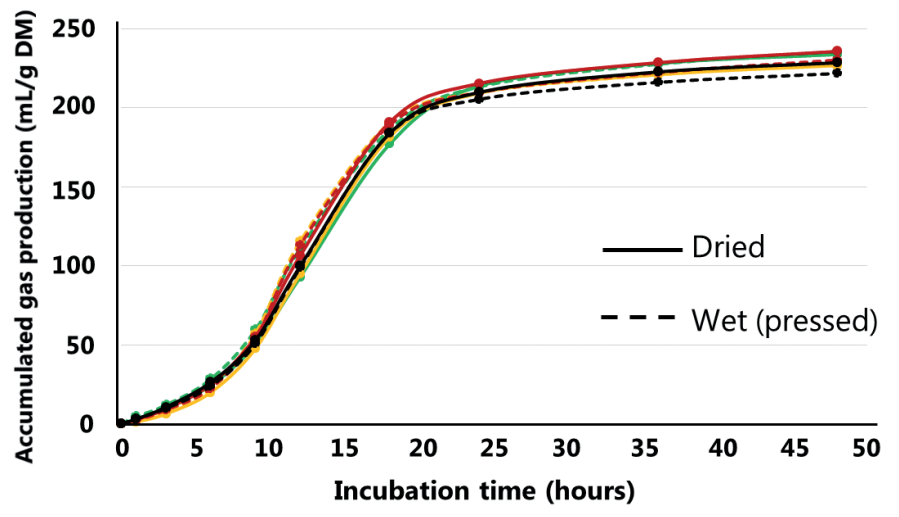

Fig. 4: Comparison of fermentation patterns (accumulated gas production in $\mathrm{mL}$ per $\mathrm{g}$ DM at STP) in beet pulp sampled on 4 different dates (differently colored lines) from one factory with a drum dryer. Broken lines represent the beet pulp before drying (freshly pressed; wet) and solid lines after drum drying (dried). Drum drying did not affect neither pattern of fermentation (accumulated gas production) nor potential degradability (after $48 \mathrm{~h}$ of fermentation)

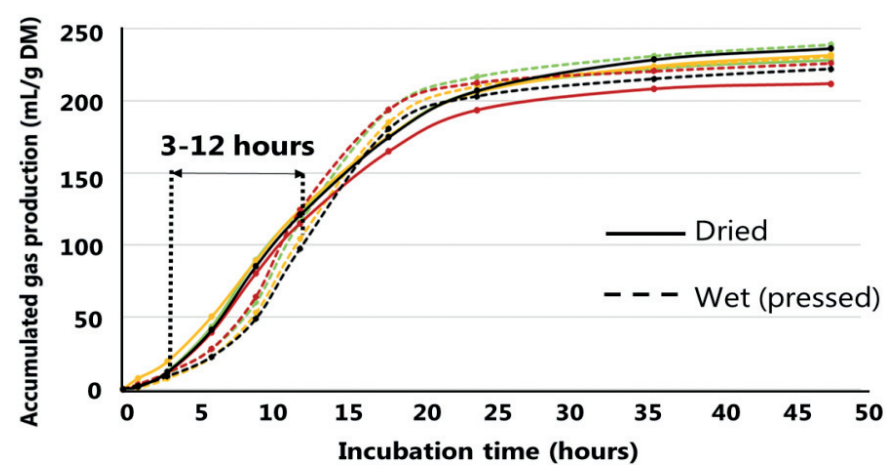

Fig. 5: Comparison of fermentation patterns (accumulated gas production) in beet pulp sampled on 4 different dates (differently colored lines) from one factory with a steam dryer.

Broken lines represent the freshly pressed beet pulp (wet) and solid lines the steam dried (dried). Steam drying increased the fermentability (accumulated gas production) over that of the freshly pressed pulp during the first $12(-15) \mathrm{h}$ of fermentation, without affecting potential degradability (after $48 \mathrm{~h}$ of fermentation).

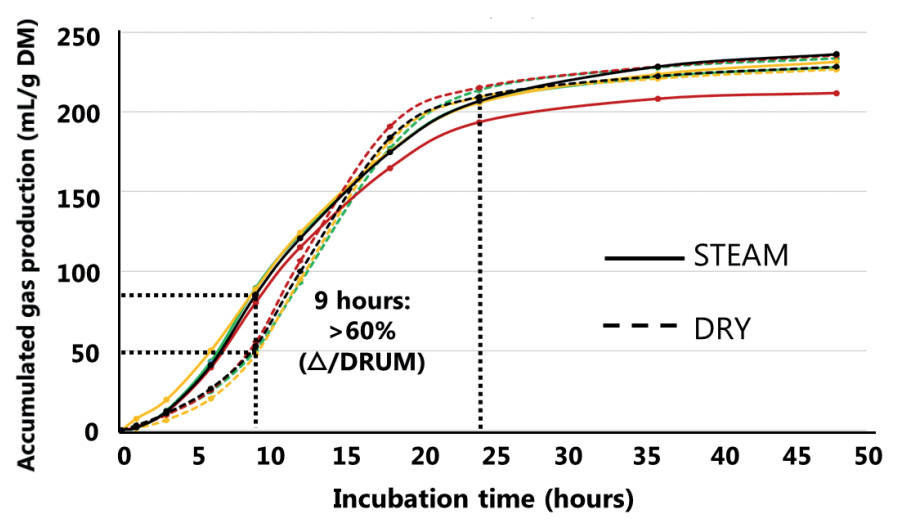

Fig. 6: Comparison of fermentation patterns (accumulated gas production) in dried beet pulp sampled on 4 different dates (differently colored lines) and dried by steam (STEAM; solid lines) or drum (DRUM; broken lines) drying.

Steam dried pulp was more easily fermentable during the first 12(-15) h of fermentation, and the difference amounted to $>60 \%$ after $9 \mathrm{~h}$ of fermentation. There were no differences in fermentation patterns of steam or drum dried pulp after $24 \mathrm{~h}$ or potential degradability (after $48 \mathrm{~h}$ of incubation) 
the first 12(-15) h of fermentation (Fig. 6), and the difference amounted to a remarkable $>60 \%$ higher fermentability (accumulated gas production) after $9 \mathrm{~h}$ of fermentation for steam dried pulp compared to drum dried pulp. After $15 \mathrm{~h}$ of incubation, there was no difference in the gas produced during fermentation of steam and drum dried beet pulp, and gas production during 24-48 h of fermentation increased in parallel in the freshly pressed and dried pulps irrespective of the drying method.

This shows that the drying processes affected how fast fermentation was initiated and proceeded during the early phases of fermentation, whereas the pattern of fermentation during the later stages of fermentation (24-48 h) were unaffected by the drying method. Thus, steam drying must have rendered the most easily fermentable fractions in the pulp more readily available for microbial degradation. A plausible explanation for that is that steam drying could cause a rupture of the plant cell wall structures, similarly to what takes place during cooking [5], and this would make the cell contents as well as the water soluble parts of the cell wall, such as pectic substances located in the middle lamella and in other cell wall layers in the beet pulp [6], more readily available for degradation by rumen microbes.

Based on these observations, one question obviously arises, namely whether such differences in the early rate of fermentation in the rumen have any implications for the nutritive value of dried beet pulp for dairy cows? Particularly since the drying process apparently has little or no impact on the total potential degradability after $24 \mathrm{~h}$ of incubation.

To be able to answer this question, it is necessary to first bear in mind that the dry matter in beet pulp, whether freshly pressed or dried, consists mainly of carbohydrates (84.1-86.2\% of $\mathrm{DM}$ ), and they are predominantly dietary fibers (appr. 76-80\% of DM) with small amounts of sugar (appr. 4.7-9.3\% of DM) accounting for the rest (values derived from analyses conducted at Eurofins Laboratory, Skive, Denmark, of paired pulp samples from the two factories [7, 8]).

Secondly, digestion of dietary fibers relies entirely on microbial degradation (fermentation) in the gut, and digestibility of beet pulp dietary fibers in dairy cows will therefore depend on two factors: 1) the time span the dietary fibers are retained in the forestomachs before flowing further into the true stomach and small intestine (hind gut fermentation contributes very little to fiber digestion due to the short retention time), and 2) the rate of degradation of the different fiber fractions within the rumen [9].

The retention time of feed components in the rumen is believed to increase almost linearly with the ingestion of feed dry matter ([9] and Fig. 7), which in turn is positively correlated to level of milk production. High-yielding dairy cows producing 35-45 kg/d milk can easily ingest $25 \mathrm{~kg}$ dry matter or more per day [10], and at this level of dry matter intake, the retention time for water soluble compounds and total concentrate dry matter will be as low as 6.7 and $13.3 \mathrm{~h}$, respectively [9], i.e. well within the time interval, where drying method had a substantial impact on beet pulp degradation. In beet pulp samples from the two factories, the water soluble fiber fraction (including pectin) accounted for $45-47 \%$ of all dry matter (Eurofins Laboratory, Skive, Denmark).

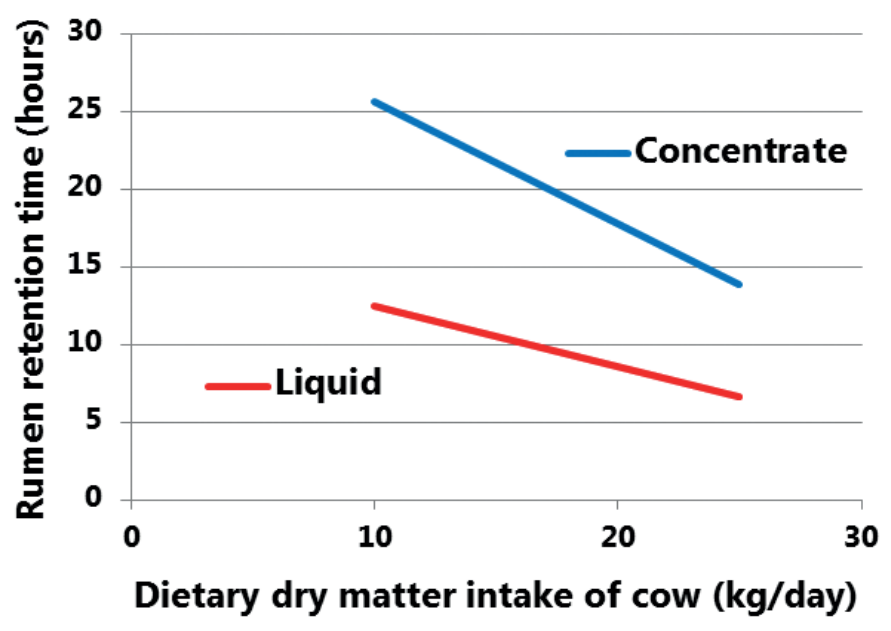

Fig. 7: Impact of dry matter intake in dairy cows on retention time in the rumen of the liquid phase (blue line) and concentrate dry matter (red line) (modified from Volden and Larsen [9]).

Intakes of 10 and $25 \mathrm{~kg}$ dry matter per day can typically be observed in dry cows and lactating cows producing 35-40 kg milk/day, respectively.

Digestion of dietary fibers relies, as already mentioned, on the microbial fermentation in the forestomachs of the cow, and fermentation can obviously only take place during the period of time the feed is actually present in the forestomachs. Therefore, if a high-yielding dairy cow with her high level of feed intake is fed beet pulp dried in a drum dryer rather than a steam dryer, $60 \%$ or more of the water soluble dietary fiber fraction in the pulp she eats will in fact flow out of the rumen before the microbiota in the rumen has ever had time to ferment it. So although the dietary fiber potentially has a high digestibility, it will become de facto indigestible for the high-yielding dairy cows due to the very low rumen retention time for water soluble substances. This must have a negative impact on the energy value of the sugar beet pulp and its value for microbial protein synthesis. The steam drying process appeared to produce a more energy rich feed for rumen microbes compared to the drum drying process as well as the unprocessed raw material.

Future feeding studies with cattle are needed to verify, if differences in early fermentation can help to explain the rather large variation observed in utilization of pectin in dairy cows from 79.4 to $95.0 \%$ according to Marounek and Duškovă [11], and to assess the quantitative impact of steam as compared to drum dried beet pulp on milk production and protein utilization in high-yielding dairy cows.

\section{References}

1 Jensen, A.S.; Larsen, K. (2015): The Development of Large Pressurized Fluid Bed Steam Driers from Fundamental Research to Industrial Plants. Drying Technol 33, 1631-1643

2 Menke, K.H.; Raab, L.; Salewski, A.; Steingass, H.; Fritz, D.; Schneider, W. (1979): The Estimation of the Digestibility and Metabolizable Energy Content of Ruminant Feedingstuffs from the Gas Production when They are Incubated with Rumen Liquor in vitro. J Agric Sci 93 217-222

3 Hannah, M.C.; Moate, P.J.; Alvarez Hess, P.S.; Russo, V.M.; Jacobs, J.L.; Eckard, R.J. (2016): Mathematical Formulae for Accurate Estimation of in vitro $\mathrm{CH}_{4}$ Production from Vented Bottles. Animal Prod Sci 56, 244-251

4 Menke, K.H.; Steingass, H. (1988): Estimation of the Energetic Feed Value obtained from Chemical Analysis and in vitro Gas Production using Rumen Fluid. Animal Res Developm 28, 7-55 


\section{Technology/Technologie}

5 Marconi, E.; Ruggeri, S.; Cappelloni, M.; Leonardi, D.; Carnovale, E. (2000): Physicochemical, Nutritional, and Microstructural Characteristics of Chickpeas (Cicer arietinum L.) and Common Beans (Phaseolus vulgaris L.) following Microwave Cooking. J Agric Food Chem 48, 5986-5994

6 Van Soest, P.J. (1994): Nutritional Ecology of the Ruminant. 2nd ed. Cornell University Press, NY

7 Dinand, E.; Chanzy, H.; Vignon, M.R. (1996): Parenchymal Cell Cellulose from Sugar Beet Pulp: Preparation and Properties. Cellulose 3, 183-188

8 Cassida, K.A.; Turner, K.E.; Foster, J.G.; Hesterman, O.B. (2007): Comparison of Detergent Fiber Analysis Methods for Forages High in Pectin. Anim Feed Sci Tech 135, 283-295
9 Volden; H.; Larsen, M. (2011): Digestion and Metabolism in the Gastrointestinal Tract. In: Volden, H. (Ed.): NORFOR - The Nordic Feed Evaluation System. Waageningen Academic Publishers, Waageningen 59-80

10 Bossen, D.; Weisbjerg, M.R.; Munksgaard, L.; Højsgaard, S. (2009): Allocation of Feed based on Individual Dairy Cow Live Weight Changes. I: Feed Intake and Live weight Changes during Lactation. Livestock Sci 126, 252272

11 Marounek, M.; Duškovă, D. (1999): Metabolism of Pectin in Rumen Bacteria Butyrivibrio fibrisolvens and Prevotella ruminicola. Lett Appl Microbiol $29,429-433$

Authors' addresses: Professor MSO Mette Olaf Nielsen and Associate Professor Hanne Helene Hansen, Department of Veterinary and Animal Sciences, The Faculty of Health and Medical Sciences, University of Copenhagen, Grønnegårdsvej 3, 1870 Frederiksberg C, Denmark; e-mail: mette.olaf.nielsen@sund.ku.dk Arne Sloth Jensen, CEO, and Kasper Larsen, Sales Director, Enerdry A/S, Kongevejen 157, 2830 Virum, Denmark 